\title{
ANALISIS PENGARUH PENANAMAN MODAL ASING, EKSPOR, UTANG LUAR NEGERI, DAN TINGKAT INFLASI TERHADAP PRODUK DOMESTIK BRUTO INDONESIA
}

\author{
Vira Andriani' ${ }^{1}$, Sri Muljaningsih ${ }^{2}$, Kiki Asmara ${ }^{3}$ \\ ${ }^{1,2,3}$ Program Studi Ekonomi Pembangunan, Fakultas Ekonomi dan Bisnis, \\ Universitas Pembangunan Nasional "Veteran" Jawa Timur, \\ Surabaya, Indonesia \\ viraandriani27@gmail.com
}

\begin{abstract}
Abstrak
Pertumbuhan ekonomi merupakan suatu ukuran kuantitatif yang mencerminkan perkembangan atau kemajuan perekonomian yang ada pada suatu negara. Salah satu konsep pendapatan nasional yang sering kali digunakan untuk mengetahui pertumbuhan ekonomi pada suatu negara yaitu Produk Domestik Bruto. Penelitian ini dilakukan dengan tujuan untuk melihat besarnya pengaruh penanaman modal asing, ekspor, utang luar negeri dan tingkat inflasi terhadap Produk Domestik Bruto Indonesia, baik secara parsial maupun simultan. dalam penelitian ini menggunakan pendekatan kuantitatif dengan menggunakan data sekunder yang diperoleh melalui website resmi lembaga atau instansi terkait, data yang digunakan adalah data selama periode 18 tahun, dari tahun 2002 sampai dengan tahun 2019. Metode analisis yang digunakan adalah analisis regresi linier berganda dan data yang diperoleh diolah dengan menggunakan bantuan program aplikasi SPSS 24.0. Hasil dalam penelitian ini menunjukkan bahwa secara simultan atau bersamaan, penanaman modal asing, ekspor, utang luar negeri dan tingkat inflasi berpengaruh signifikan terhadap Produk Domestik Bruto Indonesia. Namun secara individu atau parsial variabel ekspor dan utang luar negeri berpengaruh signifikan dan positif terhadap Produk Domestik Bruto Indonesia, sedangkan variabel penanaman modal asing dan tingkat inflasi tidak berpengaruh signifikan terhadap Produk Domestik Bruto Indonesia.
\end{abstract}

Kata Kunci: PDB, PMA, Ekspor, ULN, Inflasi

\begin{abstract}
Economic growth is a quantitative measure that reflects the development or progress of the economy in a country. One of the concepts of national income that is often used to determine economic growth in a country is the Gross Domestic Product. This study was carried out with the aim of looking at the size of the effect of foreign direct investment, exports, foreign debt and the level of inflation on Indonesia's Gross Domestic Product, either partially or simultaneously. in this study using a quantitative approach using secondary data obtained through the website official of the relevant agencies or institutions, the data used is data for a period of 18 years, from 2002 to 2019. The analysis method used in this study is multiple linear regression analysis and the data obtained is processed using the help of the SPSS 24.0. application. The results of this study show that simultaneously or collectively, foreign direct investment, exports, foreign debt and the level of inflation have a significant effect on Indonesia's Gross Domestic Product. However, individually the export and foreign debt variables have a significant and positive effect on Indonesia's Gross Domestic Product, while the foreign direct investment variable and the inflation rate do not have a significant effect on Indonesia's Gross Domestic Product.
\end{abstract}

Keywords: GDP, FDI, Exports, Foreign Debt, Inflation 


\section{PENDAHULUAN}

Ukuran kuantitatif yang mencerminkan maju atau berkembangnya perekonomian yang ada pada suatu negara yaitu dengan pertumbuhan ekonomi. Pertumbuhan ekonomi sendiri artinya meningkatnya kegiatan pada sektor ekonomi yang mengakibatkan produk ataupun jasa yang dihasilkan mengalami pertambahan serta dibarengi dengan meningkatnya kesejahteraan dan kemakmuran pada masyarakat (Sukirno dalam Defarahmi dan Zulkifli, 2017). Peningkatan pada berbagai aktivitas ekonomi di suatu negara dapat diamati melalui meningkatnya pendapatan nasional. Salah satu konsep pendapatan nasional yang sering kali digunakan untuk mengetahui pertumbuhan ekonomi yakni Produk Domestik Bruto atau PDB. PDB ialah nilai secara menyeluruh output produk serta output jasa akhir yang telah dihasilkan oleh aktivitas perekonomian pada sebuah negara pada periode 1 tahun, juga meliputi hasil produksi dan juga jasa oleh perusahaan milik negara itu sendiri maupun penduduk asing yang menetap dan bertempat tinggal di negara yang bersangkutan dan dinyatakan dengan berdasarkan harga pasar (Latumerissa, 2015).

Menurut Warkawani dkk., (2020) Besarnya angka PDB yang telah dicapai merupakan sebuah sudut pandang yang signifikan untuk mengetahui sejauh mana kinerja perekonomian suatu negara memproduksi output pemenuh permintaan oleh berbagai pelaku ekonomi. PDB juga dipergunakan sebagai pengukur standart hidup antar negara, banyak dan hampir semua negara-negara dari berbagai belahan dunia yang menggunakan PDB sebagai indikator untuk melakukan perencanaan dan memformulasikan kebijakan yang akan diterapkan karena angka dari PDB dinilai telah memuat informasi mengenai gambaran perekonomian negara secara keseluruhan.

Menurut data dari World Bank, nilai PDB Indonesia harga konstan 2010 tahun 2016-2019 terus mengalami peningkatan pada setiap tahunnya, tetapi persentase peningkatannya cenderung tidak stabil yang dapat disajikan dalam grafik berikut:

\section{Gambar 1. Grafik PDB Indonesia Harga Konstan 2010 Tahun 2016-2019}

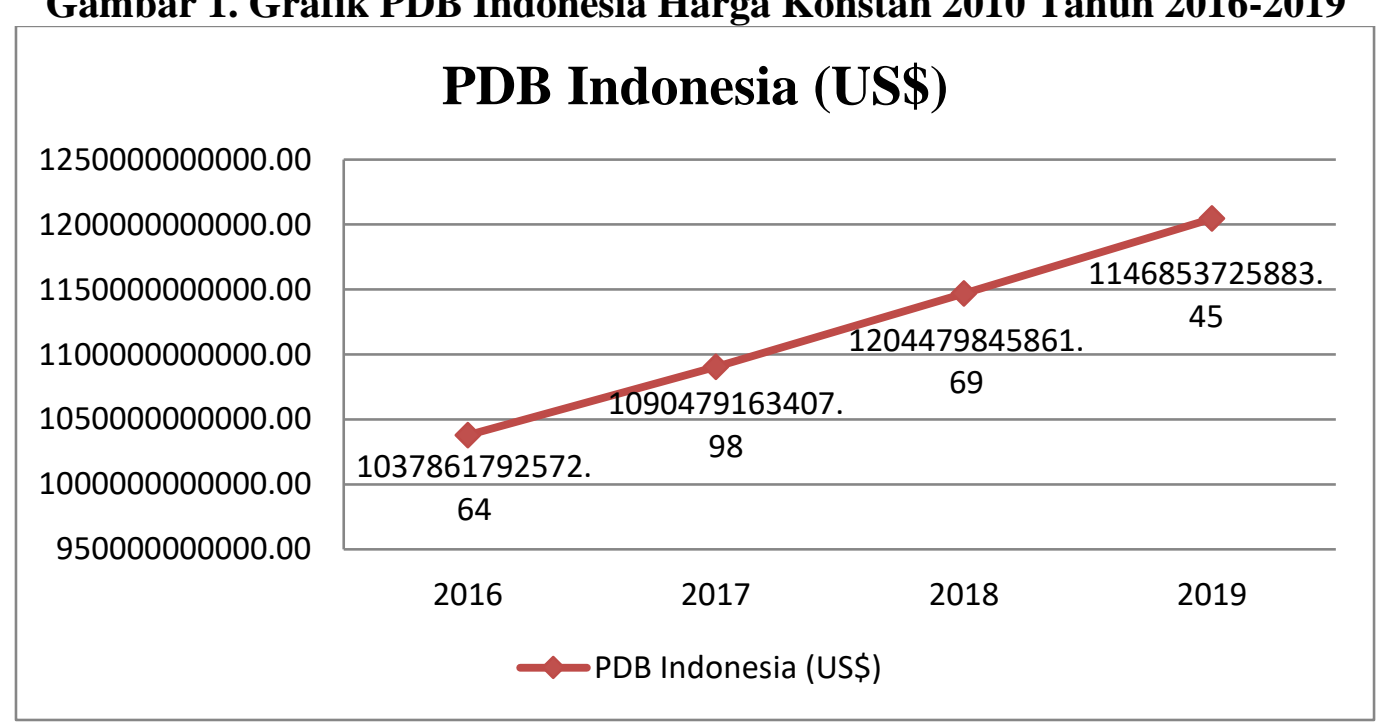

Sumber: World Bank (diolah), 2021

Pada tahun 2016 nilai PDB Indonesia tercatat sebesar 1037861792572.64 US\$, dan pada tahun 2017 meningkat menjadi 1090479163407.98 US\$ atau mengalami peningkatan sebesar $5.07 \%$. Kemudian pada tahun 2018 kembali meningkat lagi menjadi 1146853725883.45 US\$ dengan persentase peningkatan sebesar 5.17\%. Dan pada tahun 2019 nilai PDB Indonesia juga terus mengalami peningkatan dengan nilai PDB yang dicapai yaitu sebesar 1204479845861.69 US\$, tetapi persentase peningkatannya hanya sebesar $5.02 \%$, lebih kecil jika dibandingkan dengan persentase peningkatan pada tahun sebelumnya.

Keberhasilan dalam meningkatnya nilai PDB tidak terlepas dari adanya peningkatan investasi. Dalam teorinya, Harrod Domar memaparkan syarat apa saja yang harus dipenuhi agar dalam jangka panjang ekonomi mencapai pertumbuhan yang luar biasa ataupun steady growth yakni perlu adanya investasi (Murni, 2016). Salah satunya investasi yang sumbernya dari negara lain atau biasa dikenal dengan penanaman modal asing. Hill dkk., dalam Shopia dan Sulasmiyati (2018) menerangkan, Penanaman Modal Asing terjadi pada saat suatu industri secara langsung menginvestasikan dananya dengan menyediakan fasilitas dalam proses produksi maupun pemasaran suatu produk di negara lain. Penanaman modal asing yang berasal dari negara maju yang masuk ke dalam negara berkembang akan mengakibatkan 
terjadinya multiplier effect seperti transfer teknologi, modal, ilmu pengetahuan, serta menejerial. Transfer tersebut memicu produktifitas juga peningkatan output nasional yang nantinya berakibat pada pendapatan nasional yang meningkat.

Selain penanaman modal asing, kegiatan ekspor juga mempunyai peran yang penting terhadap PDB Indonesia. Salvatore (dalam Shopia dan Sulasmiyati, 2018) mengemukakan bahwa kegiatan ekspor atau mengirim barang ke luar negeri menjadi alat pendongkrak pertumbuhan ekonomi untuk negara yang tengah berkembang misalnya Indonesia. Meningkatnya ekspor akan mengakibatkan bertambahnya produksi yang ada di dalam negeri dan kemudian memerlukan input yang berbentuk tenaga kerja, sehingga secara langsung akan berdampak kepada penyerapan jumlah tenaga kerja dan juga meningkatnya pendapatan nasional atau PDB suatu negara (Febriyanti, 2019).

Dalam berjalannya pembangunan ekonomi di negara berkembang seperti Indonesia, sumber pembiayaan pembangunan ekonomi yang kerap digunakan yaitu utang luar negeri atau disebut ULN. Menurut Yustika (dalam Shopia dan Sulasmiyati, 2018) suatu instrument yang sangat umum serta diterima sebagai alternatif pilihan terbaik untuk memesatkan pembangunan infrastruktur di negara berkembang yaitu utang luar negeri. Perekonomian suatu negara sangat membutuhkan peranan dari utang luar negeri dalam dengan tujuan untuk membantu proses produksi di dalam negeri.

PDB Indonesia yang dicapai juga tidak terlepas dari adanya pengaruh dari inflasi. Inflasi merupakan satu keadaan yang menggambarkan naiknya tingkat harga barang umum di masyarakat dan terjadi secara berkelanjutan atau terus-menerus. Cepatnya inflasi merupakan suatu hal yang menyebabkan destabilisasi ekonomi terbesar yang bisa memberikan hambatan terhadap pembangunan ekonomi dan nantinya akan berdampak pada penurunan pendapatan nasional. Hal ini terjadi dikarenakan inflasi pada tingkat yang terlalu tinggi akan menyulitkan proses berusaha pada umumnya, karena menyebabkan biaya produksi mengalami peningkatan sehingga mengurangi daya saing para pelaku usaha dan menjadikan menurunnya tingkat produktivitas (Warkawani dkk., 2020).

Berdasarkan pemaparan latar belakang di atas, terlihat bahwa penanaman modal asing, ekspor, utang luar negeri, dan inflasi mempunyai indikasi terhadap nilai Produk Domestik Bruto Indonesia. Maka penulis tertarik untuk menganalisis permasalahan yang ada yaitu dengan mengangkat judul "Analisis Pengaruh Penanaman Modal Asing, Ekspor, Utang Luar Negeri, dan Tingkat Inflasi Terhadap Produk Domestik Bruto Indonesia".

\section{TINJAUAN PUSTAKA}

\section{Produk Domestik Bruto (PDB)}

Menurut Naf'an (2014), PDB atau Produk Domestik Bruto yang disebut dengan Gross Domestic Product (GDP) ialah nilai pasar untuk keseluruhan produk serta jasa akhir yang dilakukan produksi pada suatu wilayah negara dalam sebuah periode yang mencakup faktor produksi yang dimiliki oleh negara itu sendiri ataupun yang dimiliki oleh warga negara asing yang melaksanakan kegiatan produksinya di negara itu.

Menurut Pujoalwanto (2014) PDB pada umumnya ialah total keseluruhan produk ataupun jasa dari hasil berbagai unit produksi pada batas wilayah sebuah negara selama satu periode, mencakup hasil produksi serta jasa yang dikeluarkan oleh lembaga atau organisasi asing yang bekerja di suatu negara yang bersangkutan. PDB menjadi suatu statistik perekonomian yang sangat penting sebab dipercaya sebagai patokan tunggal yang paling baik untuk pengukuran kemakmuran masyarakat pada suatu negara. Semakin besar output yang dihasilkan, maka pendapatan nasional atau nilai PDB riil yang dicapai oleh negara tersebut juga akan semakin tinggi. Terjadinya peningkatan terhadap nilai PDB setiap tahunnya juga mengindikasikan bahwa perekonomian pada suatu negara lebih baik dari tahun sebelumnya.

Metode yang digunakan dalam perhitungan PDB salah satunya yaitu dengan menggunakan pendekatan pengeluaran. Murni (2016) menjelaskan bahwa pendekatan pengeluaran menghitung dengan metode melakukan penjumlahan terhadap pengeluaran atau belanja yang dilaksanakan oleh seluruh pihak seperti RTK, RTP, RTN, dan RTLN dalam pembelian suatu barang ataupun jasa pada periode tertentu pada umumnya 1 tahun. Kategori pengeluaran dari pendekatan ini adalah Pengeluaran konsumsi rumah tangga (C), Investasi (I), Belanja pemerintah (G), dan Ekspor Neto (X-M). Sehingga dapat dirumuskan :

$$
\mathbf{Y}=\mathbf{C}+\mathbf{I}+\mathbf{G}+(\mathbf{X}-\mathbf{M})
$$

\section{Penanaman Modal Asing}

Berdasarkan UU No 5 tahun 2007 yang didalamnya membahas mengenai penanaman modal pasal 1 angka 3 , penanaman modal asing ialah aktivitas penanaman modal yang bertujuan untuk melaksanakan kegiatan di wilayah negara Indonesia yang dilaksanakan oleh pihak yang menanamkan modal asing, bisa dengan memakai modal asing secara penuh ataupun dengan cara patungan dengan pihak yang menanamkan modal pada sebuah negara.

Investasi luar negeri yang berupa penanaman modal asing melahirkan suatu faktor 
pendukung bagi kemajuan suatu negara, hal ini disebabkan karena adanya dukungan dana, teknologi, serta para ahli di bidangnya. Penanaman Modal Asing yang masuk dan tumbuh di Indonesia berdampak menciptakan berbagai industri baru yang nantinya bisa menambah tingkat produktifitas barang ataupun jasa, disamping itu akan berimbas kepada penyerapan tenaga kerja dan dari situlah pendapatan yang diperoleh masyarakat akan meningkat.

\section{Ekspor}

Kegiatan ekspor merupakan aktivitas perdagangan internasional dalam bentuk mengirim dan menjual barang ataupun jasa pada pasar luar negeri. Aktivitas ekspor menyebabkan tersalurnya barang ke negara lain dengan imbalan yang didapatkan berupa pendapatan berbentuk devisa yang masuk ke dalam negara (Karya dan Syamsuddin, 2016).

Menurut Todaro (dalam Rudiawan dan Meirinaldi, 2019) ekspor menggambarkan kegiatan perdagangan antar negara yang mampu memberi rangsangan pada dinamika perkembangan perdagangan internasional, oleh karena itu negara yang tengah berkembang mempunyai kesempatan untuk mendapatkan ekonomi yang sebanding dengan berbagai negara maju lainnya.

Dalam pengertian Jhingan (2000) menyebutkan bahwa negara nantinya akan mendapatkan profitabilitas serta pendapatan nasional sebuah negara meningkat jika negara tersebut melaksanakan kegiatan ekspor, hal tersebut tergolong pada fungsi penting komponen ekspor sebagai perdagangan luar negeri yang pada dasarnya meningkatkan total output serta perkembangan ekonomi suatu negara. Negara dengan tingkat kemiskinan yang sangat parah dapat ditaklukan sebab dengan besarnya output yang dihasilkan pembangunan ekonomi bisa dilakukan secara terus-menerus.

Apabila ekspor suatu negara tinggi maka volume permintaan jasa ataupun barang mengalami peningkatan serta menjadikan bertambahnya jumlah lapangan pekerjaan sehingga sumber daya manusia yang berproduksi semakin banyak. Dari situlah ekspor sangat mempengaruhi PDB dan dapat meningkatkan pertumbuhan ekonomi suatu negara (Febriyanti, 2019).

\section{Utang Luar Negeri}

Utang luar negeri atau ULN diartikan sebagai segala pembiayaan dengan pinjaman yang didapatkan oleh pemerintah dari diberikannya utang oleh negara lain yang terkait dalam suatu kesepakatan peminjaman yang tidak berupa surat berharga negara yang nantinya wajib dibayarkan dengan suatu perjanjian yang telah disepakati (Shopia dan Sulasmiyati, 2018).
Menurut Tribroto (dalam Malik dan Kurnia, 2017) terdapat beberapa aspek yang dapat mendefinisikan utang luar negeri. Menurut aspek materi, hutang luar negeri yaitu penerimaan dana modal yang berasal dari luar negara yang dimanfaatkan sebagai aspek tambahan modal pada suatu negara. Menurut aspek formal, hutang luar negeri diartikan sebagai penerimaan yang bisa dimanfaatkan sebagai peningkatan investasi yang akan memberikan tunjangan terhadap perkembangan ekonomi. Sedangkan menurut aspek fungsi, utang luar negeri termasuk suatu alternatif sumber pembiayaan yang dibutuhkan pada pembangunan nasional. Dengan adanya pilihan alternatif pembiayaan pembangunan dalam bentuk utang luar negeri ini, diharapkan mampu memperbesar jumlah tabungan domestic dan nantinya akan memicu investasi sehingga berdampak pada meningkatkan perkembangan ekonomi.

Utang luar negeri mempengaruhi nilai PDB Indonesia, hal ini dikarenakan dari pihak pemerintah atau negara maupun dari pihak swasta menggunakan utang luar negeri guna untuk menunjang pembangunan perekonomian negara diantaranya untuk mendukung perekonomian serta defisit anggaran negara yang tidak sanggup melakukan pembiayaan terhadap pembangunan seluruhnya (Khair dan Rusydi, 2016).

\section{Inflasi}

Inflasi adalah kondisi yang terjadi dimana meningkatnya harga produk ataupun jasa dan biasanya bisa berlangsung secara terus-menerus selama masa yang telah ditentukan serta diperlihatkan pada bentuk persentase. Inflasi juga diartikan sebagai kecenderungan naiknya berbagai harga barang secara umum serta terjadi secara terusmenerus Pada kurun waktu tertentu yang dapat dibilang relatif lama. Harga dari sebuah ataupun berbagai barang saja yang mengalami kenaikan tidak bisa dinyatakan sebagai inflasi, kecuali jika kenaikannya mengalami perluasan sehingga menyebabkan lonjakan harga sebagian besar barang lain (Boediono, 2009). Tingkat inflasi yang semakin tinggi, menyebabkan produsen yang berkecimpung di dunia bisnis akan merasakan kenaikan biaya produksi akibat dari kenaikan bahan baku oleh karena itu harga jual barang domestik menjadi lebih mahal serta akan membuat daya beli warga masyarakat menurun yang mengakibatkan tidak berjalannya roda perekonomian sehingga pendapatan nasional yang dicapai juga akan menurun (Tandelilin, 2001).

Boediono (2001) dalam bukunya menyatakan bahwa inflasi dapat digolongkan menjadi dua macam :

1) Berdasarkan parah atau tidaknya inflasi : a. Inflasi ringan $<10 \%$ setahun. 
b. Inflasi sedang antara $10-30 \%$ setahun.

c. Inflasi berat antara 30-100\% setahun.

d. Hiperinflasi $<100 \%$ setahun.

2) Sesuai asal dari inflasi, dibedakan menjadi Domestic Inflation atau inflasi berasal dari dalam negeri dan Imported Inflation atau bersumber dari luar negeri.

\section{METODE PENELITIAN}

Kajian ini mempunyai sifat kuantitatif. Pada kajian ini variabel dependennya yakni nilai PDB Indonesia harga konstan 2010 dengan satuan US\$ dengan variabel independen antara lain Penanaman Modal Asing dengan satuan juta US\$, Ekspor dengan satuan juta US\$, Utang Luar Negeri dengan satuan US\$, dan tingkat inflasi dengan satuan \% (persen).

\section{Populasi dan Sampel}

Populasi yang dipakai yakni seluruh data PDB Indonesia, penanaman modal asing, ekspor, utang luar negeri, dan inflasi Indonesia. Sedangkan data yang dipakai sebagai sampel yaitu data tahunan (time series) pada periode 18 tahun, terhitung dari tahun 2002-2019.

\section{Jenis dan Sumber Data}

Data sekunder merupakan jenis data yang dipakai pada kajian ini yang didapatkan dan dikumpulkan dari beberapa lembaga/instansi yang memiliki keterkaitan dengan penelitian ini. Sumber perolehan data diperoleh melalui website resmi World Bank (www.worldbank.org) dan Badan Pusat Statistik / BPS (www.bps.go.id).

\section{Teknik Pengumpulan Data}

Metode yang digunakan dalam mengumpulkan data pada kajian ini dilaksanakan dengan melalui studi kepustakaan menggunakan berbagai jurnal dari kajian yang sebelumnya dilakukan serta dengan menggunakan buku literatur sebagai dasar pengambilan data, kemudian dilakukan pengolahan berdasarkan kebutuhan penelitian.

\section{Teknik Analisis Data}

Kajian ini memakai teknik analisis regresi linear berganda. Analisis ini dipakai untuk menganalisa pengaruh serta hubungan pada variabel bebas yang berjumlah lebih dari 2 terhadap variabel terikat. Olah data dalam kajian ini dibantu dengan aplikasi SPSS versi 24.0 dengan persamaan yang didapat seperti berikut:

$$
Y=a+\beta_{1} X_{1}+\beta_{2} X_{2}+\beta_{3} X_{3}+\beta_{4} X_{4}
$$

Dimana :

$\begin{array}{ll}\mathrm{Y} & =\text { PDB Indonesia } \\ \mathrm{a} & =\text { Konstanta Persamaan Regresi } \\ \mathrm{X}_{1} & =\text { Penanaman Modal Asing } \\ \mathrm{X}_{2} & =\text { Ekspor } \\ \mathrm{X}_{3} & =\text { Utang Luar Negeri } \\ \mathrm{X}_{4} & =\text { Inflasi } \\ \beta_{1} \beta_{2} \beta_{3} \beta_{4} & =\text { Koefisien Regresi }\end{array}$

\section{HASIL DAN PEMBAHASAN}

\section{Uji Asumsi Klasik}

Sebuah persamaan regresi wajib mempunyai sifat BLUE (Best Linier Unbiazed Estimator) yang berarti tidak diperbolehkan bias pada pengambilan dengan menggunakan uji $\mathrm{F}$ dan uji t. Tiga asumsi dasar yang harus dipatuhi dan tidak boleh dilanggar yaitu Autokorelasi, Multikolinieritas, dan Heterokedastisitas. Apabila asumsi klasik terpenuhi maka model regresi bisa dan layak dipakai sebagai instrumen estimasi kajian (Ghozali, 2016).

\section{Uji Autokorelasi}

Metode yang bisa dipergunakan untuk melakukan pendeteksian keberadaan gejala autokorelasi ialah dengan dilakukannya uji DurbinWatson atau DW Test. Dan hasil pengujiannya dapat dipaparkan pada tabel hasil uji autokorelasi seperti berikut :

Tabel 1. Hasil Uji Autokorelasi

\begin{tabular}{rrrrrr} 
Model & R & R Square & $\begin{array}{c}\text { Adjusted R } \\
\text { Square }\end{array}$ & $\begin{array}{c}\text { Std. Error of the } \\
\text { Estimate }\end{array}$ & $\begin{array}{c}\text { Durbin- } \\
\text { Watson }\end{array}$ \\
\hline 1 &, $995^{\mathrm{a}}$ &, 989 &, 986 & $2,67335 \mathrm{E}+10$ &, 903 \\
\hline
\end{tabular}

Sumber: Hasil Output SPSS Versi 24.0 (2021)

Pada tabel hasil uji autokorelasi di atas diketahui nilai $D W$ test sebesar 0,903 nilai $D W$ tabel menggunakan signifikansi $5 \%$ dengan $\mathrm{k}=4$ dan $\mathrm{n}=18$ menghasilkan nilai DW tabel senilai $\mathrm{dL}=0,8204$ serta $\mathrm{dU}=1,8719$ sehingga berada di antara wilayah dL dan dU yang artinya berada pada daerah keragu-raguan. Maka dapat disimpulkan tidak ditemukan masalah autokorelasi sehingga pengujian dapat dilanjutkan pada tahap selanjutnya. 


\section{Uji Multikolinieritas}

Metode yang bisa dipakai untuk melakukan pendeteksian keberadaan gejala multikolinearitas ialah dengan memperhatikan nilai VIF (Varians Inflating Factors) dan Tolerance. Hasil pengujian mulikolinieritas adalah berikut :

Tabel 2. Hasil Uji Multikolinieritas

\begin{tabular}{|c|c|c|c|c|c|}
\hline \multirow[b]{2}{*}{ Mode } & & \multicolumn{2}{|c|}{ Unstandardized Coefficients } & \multicolumn{2}{|c|}{ Collinearity Statistics } \\
\hline & & $\mathrm{B}$ & Std. Error & Tolerance & VIF \\
\hline \multirow[t]{5}{*}{1} & (Constant) & $2,074 \mathrm{E}+11$ & $3,306 \mathrm{E}+10$ & & \\
\hline & PMA & $-2821196,117$ & 2086566,862 & , 116 & 8,620 \\
\hline & Ekspor & 758760,336 & 219429,244 & 405 & 2,469 \\
\hline & ULN & 2,388 & ,200 &, 121 & 8,248 \\
\hline & Inflasi & -600359707 & 2094223153 & 689 & 1,451 \\
\hline
\end{tabular}

Sumber: Hasil Output SPSS Versi 24.0 (2021)

Melalui tabel 2 tersebut diketahui jika keempat variabel bebas masing-masing memiliki nilai Tolerance $>0,01$ dan nilai $V I F<10,00$ sehingga bisa ditarik kesimpulan jika tidak ada ataupun tidak terjadi gejala multikolinearitas pada gambar variabel bebas yang dipakai pada kajian ini.

\section{Uji Heterokedastisitas}

Metode yang bisa dipakai untuk melakukan pendeteksian keberadaan gejala heteroskedastisitas yaitu dengan melihat nilai Sig dari setiap residual variabel bebasnya. Hasil pengujiannya bisa dicantumkan melalui tabel berikut:

Tabel 3. Hasil Uji Heterokedastisitas

\begin{tabular}{lllc}
\hline & & & Unstandardized Residual \\
\hline Spearman's rho & PMA & Sig. (2-tailed) &, 842 \\
& Ekspor & Sig. (2-tailed) &, 548 \\
& ULN & Sig. (2-tailed) &, 633 \\
& Inflasi & Sig. (2-tailed) &, 861 \\
& Unstandarized Residual & Sig. (2-tailed) & - \\
\hline
\end{tabular}

Sumber: Hasil Output SPSS Versi 24.0 (2021)

Dari tabel 3 di atas bisa diketahui jika keempat variabel bebas masing-masing residual mempunyai nilai $\mathrm{Sig}>0,05$ yang menandakan tidak ditemukan permasalahan atau gejala heterokedastisitas dalam model penelitian ini dan dapat dilakukan analisis yang selanjutnya.

\section{Analisis Regresi Linier Berganda}

Dari hasil uji analisis regresi linier berganda diperoleh persamaan di bawah ini :

$$
\begin{gathered}
\mathrm{Y}=2,074 \mathrm{E}+11-2821196,117 \mathrm{X}_{1}+758760,336 \mathrm{X}_{2} \\
+2,388 \mathrm{X}_{3}-600359707 \mathrm{X}_{4}
\end{gathered}
$$

Persamaan di atas bisa dijabarkan antara lain sebagai berikut:

1. Nilai konstanta sebesar 2,074E+11 artinya apabila Penanaman Modal Asing $\left(\mathrm{X}_{1}\right)$, Ekspor $\left(\mathrm{X}_{2}\right)$, Utang Luar Negeri $\left(\mathrm{X}_{3}\right)$, Inflasi $\left(\mathrm{X}_{4}\right)$ dianggap konstan maka nilai PDB Indonesia (Y) akan meningkat sebesar 207400000000 US\$.

2. Nilai koefisien $\left(\beta_{1}\right)$ sebesar -2821196,117 yang berarti apabila Penanaman Modal Asing
$\left(\mathrm{X}_{1}\right)$ naik sebesar 1 juta US\$ maka nilai PDB Indonesia (Y) akan turun sebesar 2821196,117 US\$ dengan anggapan $X_{2}, X_{3}$, dan $X_{4}$ konstan.

3. Nilai koefisien $\left(\beta_{2}\right)$ sebesar 758760,336 yang berarti apabila Ekspor $\left(\mathrm{X}_{2}\right)$ naik sebesar 1 juta US\$ maka nilai PDB Indonesia (Y) akan meningkat sebesar 758760,336 US\$ dengan anggapan $\mathrm{X}_{1}, \mathrm{X}_{3}$, dan $\mathrm{X}_{4}$ konstan.

4. Nilai koefisien $\left(\beta_{3}\right)$ sebesar 2,388 yang bermakna jika Utang Luar Negeri $\left(\mathrm{X}_{3}\right)$ naik senilai 1 juta US\$ sehingga nilai PDB Indonesia (Y) akan meningkat senilai 2,388 US\$ dengan anggapan $\mathrm{X}_{1}, \mathrm{X}_{2}$, dan $\mathrm{X}_{4}$ konstan.

5. Nilai koefisien $\left(\beta_{4}\right)$ sebesar -600359707 yang berarti apabila Inflasi $\left(\mathrm{X}_{4}\right)$ naik sebesar 1 juta US\$ maka nilai PDB Indonesia (Y) akan turun sebesar -600359707 US\$ dengan anggapan $\mathrm{X}_{1}, \mathrm{X}_{2}$, dan $\mathrm{X}_{3}$ konstan. 
Analisis Koefisien Determinasi $\left(\mathbf{R}^{2}\right)$

Koefisien determinasi $\left(\mathrm{R}^{2}\right)$ dilakukan untuk mengukur seberapa besar atau seberapa jauh kemampuan suatu model regresi menjelaskan variasi dari variabel terikatnya.

Tabel 4. Hasil Koefisien Determinasi $\left(\mathrm{R}^{2}\right)$

\begin{tabular}{|c|c|c|c|c|}
\hline Model & $\mathrm{R}$ & R Square & $\begin{array}{l}\text { Adjusted R } \\
\text { Square } \\
\end{array}$ & $\begin{array}{l}\text { Std. Error of the } \\
\text { Estimate }\end{array}$ \\
\hline 1 &, $995^{\mathrm{a}}$ & ,989 & ,986 & $2,67335 \mathrm{E}+10$ \\
\hline
\end{tabular}

Sumber: Hasil Output SPSS Versi 24.0 (2021)

Dari tabel koefisien determinasi tersebut memperlihatkan besarnya nilai $\mathrm{R}$ Square $\left(\mathrm{R}^{2}\right)$ yaitu sebesar 0,989 atau $98,9 \%$. Yang berarti besarnya kemampuan semua variabel bebas Seperti Penanaman Modal Asing, Ekspor, Utang Luar Negeri, dan Inflasi menjelaskan variasi dari variabel terikatnya yaitu PDB Indonesia senilai $98,9 \%$ dan sisanya sebesar $1,1 \%$ dilakukan penjelasan oleh berbagai variabel lainnya di luar model.

\section{Pengujian Hipotesis \\ Uji Simultan (Uji F)}

Uji $F$ atau secara simultan dilaksanakan untuk melihat seberapa besar pengaruh variabel bebas terhadap variabel terikat secara simultan. Hasil pengujian dalam uji ini disajikan melalui tabel 5 seperti berikut:

Tabel 5. Hasil Uji Simultan (Uji F)

\begin{tabular}{|c|c|c|c|c|c|c|}
\hline \multicolumn{2}{|c|}{ Model } & Sum of Squares & $\mathrm{df}$ & Mean Squares & $\mathrm{F}$ & Sig. \\
\hline \multirow[t]{3}{*}{1} & Regression & $8,683 \mathrm{E}+23$ & 4 & $2,171 \mathrm{E}+23$ & 303,750 & $0,000^{b}$ \\
\hline & Residual & $9,291 \mathrm{E}+21$ & 13 & $7,147 \mathrm{E}+20$ & & \\
\hline & Total & $8,776 \mathrm{E}+23$ & 17 & & & \\
\hline
\end{tabular}

Sumber: Hasil Output SPSS Versi 24.0 (2021)

Dari hasil tersebut didapatkan nilai F hitung adalah senilai 303,750 dengan tingkat signifikannya yaitu $0,000^{\mathrm{b}}<$ taraf signifikansi 0,05 . Sedangkan nilai $\mathrm{F}$ tabel dengan $\mathrm{df}_{1} /$ degree of freedom adalah 4 dan $\mathrm{df}_{2}$ adalah 13 (n-k-1), maka diperoleh $\mathrm{F}$ tabel senilai 3,18. Menurut pengujian ini diketahui jika nilai $\mathrm{F}$ hitung $303,750>\mathrm{F}$ tabel 3,18 sehingga $\mathrm{H} 0$ dinyatakan ditolak dan $\mathrm{H} 1$ diterima, yang berarti secara simultan Penanaman Modal Asing, Ekspor,
Utang Luar Negeri, dan Inflasi memberikan pengaruh yang signifikan pada PDB Indonesia.

\section{Uji Parsial (Uji t)}

Uji t statistik dipakai untuk mengetahui pengaruh dari setiap variabel bebas secara individu pada variabel terikatnya.

Tabel 6. Hasil Uji Parsial (Uji t)

\begin{tabular}{|c|c|c|c|c|c|c|}
\hline \multirow{2}{*}{\multicolumn{2}{|c|}{ Model }} & \multicolumn{2}{|c|}{ Unstandardized Coefficients } & \multirow{2}{*}{$\begin{array}{c}\text { Standardized } \\
\text { Coefficients }\end{array}$} & \multirow[b]{2}{*}{$\mathrm{t}$} & \multirow[b]{2}{*}{ Sig. } \\
\hline & & $\mathrm{B}$ & Std. Error & & & \\
\hline 1 & (Constant) & $2,074 \mathrm{E}+11$ & $3,306 \mathrm{E}+10$ & & 6,274 &, 000 \\
\hline & PMA & $-2821196,117$ & 2086566,862 &,- 113 & $-1,352$ & 199 \\
\hline & Ekspor & 758760,336 & 219429,244 & ,155 & 3,458 & ,004 \\
\hline & ULN & 2,388 & ,200 & 977 & 11,917 & ,000 \\
\hline & Inflasi & -600359707 & 2094223153 &,- 010 &,- 287 &,- 779 \\
\hline
\end{tabular}

Sumber: Hasil Output SPSS Versi 24.0 (2021)

Melalui tabel uji parsial di atas dapat dilihat hasil uji dari setiap variabel bebas ialah seperti berikut:
1. Uji t terhadap Penanaman Modal Asing $\left(X_{1}\right)$. Hasil pengujian diperoleh nilai t hitung yaitu senilai -1,352 dan nilai t tabel sebesar 2,16037 
maka $\mathrm{t}$ hitung < $\mathrm{t}$ tabel dengan signifikansi $\mathrm{t}$ sebesar 0,199 atau $0,199>\alpha(0,05)$ yang memperlihatkan jika $\mathrm{HO}$ dinyatakan diterima. Maka dapat diambil kesimpulan jika penanaman modal asing tidak berpengaruh signifikan terhadap PDB Indonesia.

2. Uji t terhadap Ekspor $\left(\mathrm{X}_{2}\right)$. Hasil pengujian menunjukkan nilai t hitung yaitu senilai 3,458 dan nilai t tabel senilai 2,16037 sehingga $t$ hitung $>\mathrm{t}$ tabel dengan signifikansi $\mathrm{t}$ sebesar 0,004 atau $0,004<\alpha(0,05)$ yang memperlihatkan jika $\mathrm{H} 0$ dinyatakan ditolak. Maka dapat diambil kesimpulan jika ekspor berpengaruh positif dan signifikan terhadap PDB Indonesia.

3. Uji t terhadap Utang Luar Negeri $\left(\mathrm{X}_{3}\right)$. Hasil pengujian menunjukkan nilai $\mathrm{t}$ hitung yaitu sebesar 11,917 dan nilai t tabel senilai 2,16037 sehingga thitung $>\mathrm{t}$ tabel, dengan signifikansi t senilai 0,000 atau $0,000<\alpha(0,05)$ yang memperlihatkan jika $\mathrm{H} 0$ dinyatakan ditolak. Maka dapat diambil kesimpulan jika utang luar negeri berpengaruh positif dan signifikan terhadap PDB Indonesia.

4. Uji t terhadap Inflasi $\left(\mathrm{X}_{4}\right)$. Hasil pengujian didapatkan nilai t hitung yaitu senilai $-0,287$ dan nilai t tabel senilai 2,16037. Sehingga $t$ hitung $<\mathrm{t}$ tabel, dengan signifikansi t sebesar 0,779 atau $0,779>\alpha(0,05)$ menunjukkan bahwa H0 diterima. Maka dapat diambil kesimpulan jika inflasi tidak berpengaruh signifikan terhadap PDB Indonesia.

\section{PEMBAHASAN}

\section{Pengaruh Penanaman Modal Asing Terhadap Produk Domestik Bruto Indonesia}

Hasil analisa secara parsial memperlihatkan jika penanaman modal asing tidak memberi pengaruh secara signifikan pada PDB Indonesia. Hal ini terjadi dikarenakan tidak stabilnya kondisi investasi Indonesia sehingga nilai investasi yang dihasilkan berfluktuasi dari tahun ke tahun sehingga Indonesia belum menjadi pilihan utama untuk calon investor asing yang hendak menanamkan dana atau modalnya ke Indonesia (Nuritasari 2013). Selain itu, teori ini diperkuat oleh Kustituanto dan Istikomah dalam Rudiawan dan Meirinaldi (2019) dimana faktor-faktor yang menyebabkan Penanaman Modal Asing tidak mempunyai pengaruh terhadap Produk Domestik Bruto yaitu disebabkan oleh : 1) Kecilnya country risk pasar dalam negeri yang menyebabkan tingkat pengembalian dari modal rendah, kurangnya infrastruktur dan dukungan fasilitas seperti transportasi, teknologi, dan tenaga kerja yang terampil. 2) Proses administrasi oleh birokrasi yang menghambat dan koordinasi antar departemen terkait yang kurang. 3) Kurangnya informasi atas sumber dana yang menghambat pembiayaan ataupun pendanaan proyek. 4) Rendahnya kualitas sumber daya manusia sehingga berakibat pada terhambatnya proses transfer investasi asing. 5) Persaingan antar negara yang ketat dalam menarik investor asing yang akan melakukan investasi ke negaranya.

Hasil kajian ini sesuai dengan kajian yang dijalankan oleh Lubis dan Riva'i (2016) dimana menyatakan ditemukannya pengaruh positif tetapi tidak signifikan diantara Penanaman Modal Asing dan PDB Indonesia. Hasil ini juga sesuai dengan Nuritasari (2013) yang menunjukkan hasil Penanaman Modal Asing memiliki pengaruh yang positif namun tidak signifikan pada PDB Indonesia.

\section{Pengaruh Ekspor Terhadap Produk Domestik Bruto Indonesia}

Secara parsial, Hasil analisa memperlihatkan jika ekspor memiliki pengaruh yang signifikan serta positif pada PDB Indonesia. Yang menandakan ekspor memberikan pengaruh baik kepada perekonomian Indonesia, dikarenakan ekspor memainkan peran penting dalam menghasilkan jumlah output dan pendapatan yang nantinya akan meningkatkan nilai PDB Indonesia. Teori ini juga diperkuat oleh teori ekonomi klasik yang dimana perluasan pasar dapat dicapai melalui kegiatan ekspor dan negara pengekspor berpeluang untuk mendapatkan dana untuk membeli barang lain salah satunya yaitu barang modal guna untuk memajukan perekonomian. Pesatnya pertumbuhan ekspor maka akan meningkatkan pengeluaran agregat suatu negara (Shopia dan Sulasmiyati, 2018).

Penelitian ini konsisten dengan penelitian Febriyanti (2019) dengan hasil ekspor mempunyai pengaruh positif terhadap PDB Indonesia. Penelitian ini juga sesuai dengan Rudiawan dan Meirinaldi (2019) yang menyimpulkan ekspor Memiliki pengaruh yang signifikan serta positif pada PDB Indonesia, yang berarti apabila ekspor mengalami peningkatan maka PDB Indonesia akan mengalami peningkatan juga.

\section{Pengaruh Utang Luar Negeri Terhadap Produk Domestik Bruto Indonesia}

Secara parsial Hasil analisa memperlihatkan jika utang luar negeri memiliki pengaruh yang signifikan serta positif pada PDB Indonesia, yang bermakna semakin tingginya utang luar negeri maka PDB Indonesia pun juga akan meningkat, sehingga nilai PDB Indonesia yang dicapai banyak dipengaruhi oleh pinjaman luar negeri. Pinjaman atau utang luar negeri dipergunakan sebagai pembangunan sarana dan infrastruktur juga mendukung pembangunan ekonomi Indonesia dengan tujuan untuk meningkatkan kesejahteraan masyarakat (Habibah, 2002). Teori ini diperkuat oleh Yustika (2009) dimana pinjaman luar negeri 
dimanfaatkan oleh negara berkembang dalam melewati kesenjangan investasi ataupun tabungan serta neraca pembayaran. Keadaan negara berkembang seperti Indonesia yang dalam perekonomiannya memerlukan sumber dana dalam melaksanakan pembangunan yang nantinya akan berpengaruh pada produktivitas yang dihasilkan.

Hasil kajian ini sesuai dengan kajian yang dijalankan oleh Rahman dkk. (2017) yang menyatakan utang luar negeri memiliki pengaruh positif signifikan terhadap PDB Indonesia, yang berarti ketika utang luar negeri meningkat, PDB Indonesia juga akan meningkat.

\section{Pengaruh Inflasi Terhadap Produk Domestik Bruto Indonesia}

Secara parsial, hasil analisis memperlihatkan jika inflasi tidak memberikan pengaruh yang signifikan pada PDB Indonesia. Pada penelitian ini rata-rata tingkat inflasi hanya sebesar $6,29 \%$ yang menandakan hanya terjadinya inflasi ringan, sedangkan inflasi akan memiliki pengaruh apabila telah mencapai pada persentase tertentu. Diperjelas dengan teori yang Samsul (2006) Tingkat inflasi bisa memberikan pengaruh yang positif ataupun negatif sesuai dengan besarnya inflasi tersebut. Apabila besarnya di bawah $10 \%$ inflasi akan berpengaruh positif atau bisa jadi tidak berpengaruh dan akan berpengaruh negatif ketika besarnya lebih dari $10 \%$. Rendah dan stabilnya inflasi dari waktu ke waktu akan menjadi simulator bagi pertumbuhan ekonomi, sedangkan tingginya tingkat inflasi yang dapat menyebabkan meruginya perekonomian secara keseluruhan dan dapat mengakibatkan kebangkrutan perusahaan.

Hasil pada kajian ini sesuai dengan kajian yang dilaksanakan oleh Warkawani dkk. (2020) yang membuktikan jika tingkat inflasi tidak memberikan pengaruh secara signifikan pada PDB Indonesia.

\section{PENUTUP}

\section{Kesimpulan}

Berdasarkan hasil analisis, uji statistik, serta pembahasan mengenai penanaman modal asing, ekspor, utang luar negeri, dan tingkat inflasi di atas, maka dapat diambil kesimpulan sebagai berikut :

1. Ekspor berpengaruh positif dan signifikan terhadap Produk Domestik Bruto Indonesia.

2. Utang Luar Negeri berpengaruh positif dan signifikan terhadap Produk Domestik Bruto Indonesia.

3. Penanaman Modal Asing tidak berpengaruh signifikan terhadap Produk Domestik Bruto Indonesia.

4. Inflasi tidak berpengaruh signifikan terhadap Produk Domestik Bruto Indonesia.
Saran

Berdasarkan pembahasan beserta kesimpulan di atas, saran yang diajukan oleh penulis adalah Pemerintah diharapkan lebih mengoptimalkan penggunaan utang luar negeri agar tanggungan yang nantinya harus dibayarkan oleh negara tidak semakin besar serta memanfaatkan hasil bumi secara maksimal agar negara tidak selalu bergantung pada utang luar negeri. Untuk penelitian yang mendatang diharapkan untuk menambahkan variabel-variabel lain di luar penelitian ini, serta menggunakan data terbaru sehingga memberikan hasil yang maksimal untuk menjelaskan hal-hal yang mempengaruhi Produk Domestik Bruto Indonesia.

\section{DAFTAR PUSTAKA}

Badan Pusat Statistik. https://www.bps.go.id/ Diakses Tanggal 16 Januari 2021

Boediono. 2001. Ekonomi Makro. Edisi 4. Yogyakarta: BPFE UGM.

2009. Ekonomi Moneter. Yogyakarta: BPFE UGM.

Defarahmi, Hafiz, and Zulkifli. 2017. "Dampak Defisit Anggaran Dan Penanaman Modal Asing Terhadap Pertumbuhan Ekonomi Indonesia." Jurnal Ilmiah Mahasiswa (JIM) Ekonomi Pembangunan Fakultas Ekonomi dan Bisnis Unsyiah 2(4): 618-25.

Febriyanti, Dea Fitri. 2019. "Pengaruh Ekspor Dan Impor Terhadap Produk Domestik Bruto Indonesia Tahun 2008-2017." Jurnal Ecoplan 2(1): 10-20.

Ghozali, Imam. 2016. Aplikasi Analisis Multivariate Dengan Program IBM SPSS 23. Semarang: BPFE Universitas Diponegoro.

Habibah, Siti Nur. 2002. Pengaruh Utang Luar Negeri, Penanaman Modal Asing, Dan Pembiayaan Bank Syariah Terhadap Produk Domestik Bruto Indonesia Periode 20122018. Surakarta: IAIN Surakarta.

Jhingan, M.L. 2000. Ekonomi Pembangunan Dan Perencanaan. Jakarta: PT Raja Grafindo Persada.

Karya, Detri, and Syamsuddin. 2016. Makroekonomi Pengantar Untuk Manajemen. Jakarta: PT Raja Grafindo Persada.

Khair, Muflihul, and Bahrul Ulum Rusydi. 2016. "Analisis Pengaruh Utang Luar Negeri (Foreign Debt) Dan Penanaman Modal Asing (PMA) Terhadap Nilai Produk Domestik Bruto (PDB) Indonesia." 
Economics, Sosial, and Development 3(1): 82.

Latumerissa, Julius R. 2015. Perekonomian Indonesia Dan Dinamika Ekonomi Global. Jakarta: Mitra Wacana Media.

Lubis, Annisa Ilmi Faried, and M Rivan Riva'i. 2016. "Analisis Pengaruh Utang Luar Negeri, Penanaman Modal Asing Dan Ekspor Terhadap Produk Domestik Bruto Di Indonesia Periode 2005-2014." Kajian Ekonomi dan Kebijakan Publik 1(2): 19-27.

Malik, Abdul, and Denny Kurnia. 2017. "Pengaruh Utang Luar Negeri Dan Penanaman Modal Asing Terhadap Pertumbuhan Ekonomi." Jurnal Akuntansi 3(2): 27-42.

Murni, Asfia. 2016. Ekonomika Makro Edisi Revisi. Bandung: PT Refika Aditama.

Naf'an. 2014. Ekonomi Makro: Tinjauan Ekonomi Syariah. Yogyakarta: Graha Ilmu.

Nuritasari, Firdausi. 2013. "Pengaruh Infrastruktur, PMDN Dan PMA Terhadap Produk Domestik Bruto Di Indonesia." Economics Development Analysis Journal 2(4): 446-55.

Pujoalwanto, Basuki. 2014. Perekonomian Indonesia; Tinjauan Historis, Teoritis, Dan Empiris. Yogyakarta: Graha Ilmu.

Rahman, B., M. Musadieq, And S. Sulasmiyati. 2017. "Pengaruh Utang Luar Negeri Dan Ekspor Terhadap Pertumbuhan Ekonomi (Studi Pada Produk Domestik Bruto Indonesia Periode 2005-2014)." Jurnal Administrasi Bisnis S1 Universitas Brawijaya 45(1): 55-62.

Rudiawan, Hendri, And Meirinaldi. 2019. “Dampak Faktor-Faktor Makro Ekonomi Terhadap Pertumbuhan Produk Domestik Bruto Indonesia." Jurnal Ekonomi 21.

Samsul, Muhamad. 2006. Pasar Modal Dan Manajemen Portofolio. Surabaya: Erlangga.

Shopia, Aya, And Sri Sulasmiyati. 2018. "Pengaruh Foreign Direct Investment, Ekspor, Dan Utang Luar Negeri Terhadap Pertumbuhan Ekonomi ASEAN (Studi Pada Produk Domestik Bruto Indonesia, Malaysia, Dan Thailand Periode Tahun 2007 - 2016)." Jurnal Administrasi Bisnis (Jab) 61(3).

Tandelilin, Eduardus. 2001. Analisis Investasi Dan Manajemen Portofolio. Yogyakarta: BPFE.

Undang-Undang Nomor 25 Tahun 2007 tentang Penanaman Modal.

Warkawani, Clansina Margareth, Noeke Chrispur, And Diah Widiawati. 2020. "Pengaruh Jumlah Uang Beredar Dan Tingkat Inflasi
Terhadap Produk Domestik Bruto (PDB) Di Indonesia Tahun 2008-2017." Journal Of Regional Economics Indonesia 1(1): 14-32.

World Bank. https://www.worldbank.org/ Diakses Tanggal 16 Januari 2021.

Yustika, Ahmad Erani. 2009. Ekonomi Politik: Kajian Teoretis Dan Analisis Empiris. Yogyakarta: Pustaka Pelajar. 